KS. WOJCIECH GÓRALSKI

Wydział Prawa Kanonicznego

Uniwersytetu Kardynała Stefana Wyszyńskiego w Warszawie

\title{
WKŁAD KARD. ZENONA GROCHOLEWSKIEGO W DZIEŁO EDUKACJI KATOLICKIEJ W ŚWIECIE
}

Treść: Wprowadzenie. -1 . Rys biograficzny. -2 . Kongregacja Wychowania Katolickiego - wczoraj i dziś. - 3. Z Sygnatury do Kongregacji. - 4. Priorytet seminariów duchownych. -5 . Wokół szkół katolickich. - 6. Troska o wyższe uczelnie kościelne i katolickie. - Zakończenie.

\section{Wprowadzenie}

Tak jak historia danego państwa czy określonej instytucji jest w dużej mierze historią ludzi, tak również historię Kościoła w niemałym stopniu tworzą jego wyznawcy. Jednym z tych, którzy w ostatnich dziesiątkach lat wnoszą do dziejów Kościoła szczególny wkład w jego rozwój, a także kształtują jego wizerunek w świecie, jest niewątpliwie kard. Zenon Grocholewski, ustępujący prefekt Kongregacji Wychowania Katolickiego, uprzednio prefekt Najwyższego Trybunału Sygnatury Apostolskiej. Wielkopolanin z urodzenia, Rzymianin z zrządzenia Bożej Opatrzności, sprawujący od 43. lat swoją posługę kapłańską, a potem biskupią u boku już czwartego Papieża, jest postacią dobrze znaną w świecie. Wybitny znawca prawa kanonicznego, autor licznych, w kilku przypadkach pionierskich prac w tej dziedzinie, długoletni profesor rzymskich uczelni, doświadczony przełożony już drugiej z kolei dykasterii kurialnej na Watykanie, duszpasterz ex animo o wielkim umyśle, ale i sercu, a przy tym pełen gorliwości o chwałę Bożą i dobro Kościoła, uhonorowany licznymi wysokimi orderami i odznaczeniami kilkunastu państw i znaczących instytucji, 
doktor honoris causa 22. uczelni w świecie, m.in. Akademii Teologii Katolickiej w Warszawie (1998), w pełni zasługuje nie tylko na wysokie uznanie, ale również na szczerą wdzięczność tych wszystkich, którym przypadło w udziale korzystać z jego posługi lub poznać bliżej jego osobę i dzieło.

Szczególną wdzięczność wobec kard. Zenona Grocholewskiego budzi jego długoletnia posługa pełniona na stanowisku prefekta Kongregacji Wychowania Katolickiego. Sprawując ten urząd powierzony mu przez Jana Pawła II od blisko 16. lat, wniósł znaczący wkład w dzieło edukacji katolickiej w świecie, w tym także w swoim ojczystym kraju.

\section{Rys biograficzny}

Zenon Grocholewski, syn Stanisława i Józefy z domu Stawińskiej, urodził się 11 października 1939 roku (w rodzinie kupieckiej) w miejscowości Bródki, niedaleko Pniew (województwo poznańskie), jako trzecie spośród czworga dzieci małżonków Grocholewskich.

Po zakończeniu działań wojennych rodzina Grocholewskich osiadła w Miedzichowie, w pobliżu Nowego Tomyśla, gdzie Zenon ukończył w 1953 roku Szkołę Podstawową, po czym kontynuował naukę w Niższym Seminarium Duchownym w Wolsztynie. Po uzyskaniu świadectwa dojrzałości, idąc za głosem powołania, w 1957 roku wstąpił do Wyższego Arcybiskupiego Seminarium Duchownego w Poznaniu, odbywając tam studia filozoficzno-teologiczne oraz formację do kapłaństwa. Święcenia kapłańskie przyjął 26 maja 1963 roku w archikatedrze poznańskiej z rąk abp. Antoniego Baraniaka. Na swoim obrazku prymicyjnym umieścił znamienne słowa wypowiedziane przez św. Jana Chrzciciela: Illum oportet crescere - „Trzeba, aby On wzrastał" (J 3,30). Powtórzy je 20 lat później na swoim obrazku upamiętniającym przyjęcie święceń biskupich.

Posługę kapłańską rozpoczął, jako wikariusz, w parafii Chrystusa Odkupiciela w Poznaniu, pełniąc ją przez trzy lata (1963-1966). Będzie do niej powracał, nawet już jako kardynał, z wielkim sentymentem, uznając ten okres za niezwykle ważny dla kształtowania własnego kapłaństwa, a zarazem szczególnie satysfakcjonujący, kiedy to doświadczał pierwszych radości duszpasterza. Ale też jego posługa 
wikariuszowska musiała głęboko zapaść w serca ówczesnych parafian, skoro wielu z nich do dzisiaj z ogromną wdzięcznością wspomina prawdziwie kapłański zapał i oddanie sprawie Bożej młodego ks. Zenona. Duszpasterzem, i to ex animo, pozostał zresztą dawny wikary z poznańskiego Osiedla Warszawskiego do dziś, podejmując nieprzerwanie różnorodne posługi kapłańskie, a potem biskupie, a także chętnie spotykając się z ludźmi i nawiązując z nimi bezpośredni dialog.

Nieprzeciętne zdolności młodego kapłana oraz jego gorliwość duszpasterska skłoniły abp. Antoniego Baraniaka do skierowania go na dalsze studia, które miał odbywać na Papieskim Uniwersytecie Gregoriańskim w Rzymie. Rozpoczął je w 1966 roku na Wydziale Prawa Kanonicznego wymienionej uczelni. Zamieszkał wówczas w Papieskim Kolegium Polskim przy Piazza Remuria. Prawo kanoniczne stało się odtąd prawdziwą pasją ks. Grocholewskiego, co ułatwiło mu wysoce kompetentne pełnienie szeregu znaczących funkcji w Kurii Rzymskiej, które go czekały. Tym bardziej, że na "Gregorianie” słuchał wykładów tak znamienitych kanonistów (będących jezuitami), jak U. Navarrete, I. Gordon, O. Robleda, J. Buis, W. Bertrams, J. Beyer czy R. Bidagor. A ponieważ wykłady i inne zajęcia uniwersyteckie prowadzone były po łacinie, przyszły purpurat posiadł doskonałą znajomość języka starożytnych Rzymian i średniowiecznej Europy. Niemałą satysfakcję musiał odczuć student „Z dalekiego kraju”, gdy po pierwszym egzaminie składanym u słynącego z surowości i wysokich wymagań o. prof. W. Bertramsa usłyszał: Optime dixisti!

W 1968 roku uzyskał ks. Grocholewski stopień licencjata, natomiast w 1972 roku obronił rozprawę doktorską pt. De exclusione indissolubilitatis ex consensu matrimoniali eiusque probatione. Considerationes super recentiores sententias rotales, przygotowaną pod kierunkiem wybitnego kanonisty hiszpańskiego I. Gordona, opublikowaną następnie drukiem (Napoli 1973, ss. 200), otrzymując stopień naukowy doktora prawa kanonicznego. Zarówno dysertacja licencjacka, jak i rozprawa doktorska zostały nagrodzone złotym medalem, który uczelnia przyznaje dla najlepszego studenta na każdym wydziale 
(jest to zwyczajowo nagroda Ojca świętego). Było to pierwsze tego rodzaju wyróżnienie dla Polaka-studenta Gregorianum po drugiej wojnie światowej.

W latach 1968-1969 oraz 1972-1974 ks. Zenon odbywał ponadto studia specjalistyczne w Studium Roty Rzymskiej, uzyskując dyplom adwokata Roty Rzymskiej. Podczas swoich studiów kanonistycznych uczęszczał ponadto na kursy językowe w Niemczech i we Francji, udzielając się również duszpastersko w Niemczech i we Włoszech.

Zrządzeniem Bożej Opatrzności 33-letni ks. dr Grocholewski, odznaczający się prawością charakteru, szczególnymi zdolnościami, dużym zapałem w podejmowaniu zadań i dobrym przygotowaniem do dalszej pracy poprzez rzetelne studia prawa kanonicznego, miał rozpocząć nową posługę w Kościele, która związała go na trwałe ze Stolicą Apostolską. Jak się okaże, otrzymywał on coraz bardziej odpowiedzialne funkcje - zarówno w sądownictwie, jak i w administracji kościelnej najwyższego szczebla. Wywiązując się sumiennie z każdego powierzanego mu - najpierw przez Pawła VI, potem przez Jana Pawła II, a następnie przez Benedykta XVI, wreszcie przez Franciszka - zadania, po wielu latach swojej chlubnie wypełnianej posługi stanie się jednym z najwybitniejszych kurialistów, wydatnie i ofiarnie wspierających Biskupów Rzymskich w pełnieniu przez nich najwyższego urzędu apostolskiego.

Długa droga powołanego przez papieża Pawła VI do posługi w Kurii Rzymskiej młodego kapłana polskiego będzie prowadzić przez dwie podstawowe „stacje”: Sygnaturę Apostolską i Kongregację Wychowania Katolickiego. Służba obecnego kardynała na rzecz Stolicy Apostolskiej ma jednak, i to od samego początku, znacznie szerszy zakres.

Po ukończeniu studiów 33-letni ks. dr Grocholewski, rekomendowany przez swojego promotora rozprawy doktorskiej, otrzymał propozycję pracy w Najwyższym Trybunale Sygnatury Apostolskiej (jeden z trzech trybunałów Stolicy Apostolskiej), którą - po uzyskaniu zgody swojego ordynariusza, abp. Antoniego Baraniaka - podjął w październiku 1972 roku na stanowisku notariusza. W ten sposób związał się na trwałe ze Stolicą Apostolską, która to więź trwa do dzisiaj. 
Po pięciu latach pracy w Sygnaturze Apostolskiej spotkał ks. dr. Zenona pierwszy awans, kiedy to w 1977 roku powierzono mu pełnienie obowiązków kanclerza Trybunału (został wówczas odznaczony godnością kapelana Jego Świątobliwości). Z kolei w roku 1980 roku otrzymał już sam urząd kanclerski.

Zyskując sobie - swoim zaangażowaniem, kompetencjami i sumiennością w pracy - coraz większe uznanie przełożonych, w szczególności kard. Aurerlio Sabbataniego, ówczesnego prefekta Sygnatury Apostolskiej, w dniu 21 grudnia 1982 papież Jan Paweł II mianował ks. prałata Grocholewskiego sekretarzem wymienionego Trybunału, wynosząc go jednocześnie do godności biskupiej (otrzymał stolicę tytularną Agropoli). To znaczące wyróżnienie 43-letniego duchownego stanowiło dlań, jak sam wspomina, niemałe zaskoczenie i szczególne przeżycie. Jeszcze większym było przyjęcie święceń biskupich z rąk Ojca świętego, co miało miejsce w uroczystość Objawienia Pańskiego, 6 stycznia 1983 roku, w Bazylice św. Piotra na Watykanie. Podczas tej ceremonii Jan Paweł II skierował do biskupa Zenona następujące słowa: „Ty, Drogi Bracie, wyruszaj i prowadź innych. Prowadź wszystkich, których Opatrzność postawi na drodze Twego powołania. Czyń wszystko, na co Cię stać, aby doszli do Betlejem. A nade wszystko sam tam stawaj, gdzie prowadzi Cię światło wiary - i czyń tak, jak uczynili Mędrcy ze Wschodu: ofiaruj Mu dary - złoto, kadzidło, mirrę. Złoto miłości, kadzidło modlitwy, mirrę cierpienia”.

Gdy w 1998 roku, po przejściu na emeryturę prefekta Sygnatury Apostolskiej, kard. Gilberto Augustoni, urząd ten zawakował, Jan Paweł II, wysoko ceniąc umiejętności prawnicze, doświadczenie oraz cechy charakteru 59-letniego wówczas arcybiskupa Zenona, jemu właśnie urząd ten powierzył, co miało miejsce 5 października wymienionego roku. Nowo mianowany prefekt tak znaczącego Trybunału Apostolskiego był wówczas najmłodszym spośród ponad trzydziestu przełożonych stojących na czele dykasterii Kurii Rzymskiej. Nominacja na prefekta Sygnatury Apostolskiej, otrzymana przez jej dawnego notariusza, kanclerza, a następnie sekretarza, stanowiła jakże zaszczytne, choć przede wszystkim bardzo zobowiązujące zwieńczenie 26-letniej, ofiarnej pracy w tym Trybunale wytrawnego już kurialisty, 
mocno wrośniętego $w$ Palazzo Cancelleria (tam też mieszkał), lecz jeszcze bardziej w Kościół Chrystusowy, z którym niebawem miał zostać zaślubiony w sposób wyjątkowy.

Na stanowisku prefekta Najwyższego Trybunału Stolicy Apostolskiej abp Grocholewski nie pozostał długo. Zaledwie bowiem po 13. miesiącach, a dokładnie 15 listopada 1999 roku, ku własnemu zaskoczeniu, otrzymał od Ojca świętego nominację na prefekta Kongregacji Wychowania Katolickiego ${ }^{1}$.

\section{Kongregacja Wychowania Katolickiego - wczoraj i dziś}

Początki dzisiejszej Kongregacji Wychowania Katolickiego sięgają roku 1588, kiedy to Sykstus V, Konstytucją apostolską Immensa aeterni Dei zorganizował Kurię Rzymską w ścisłym tego słowa znaczeniu. Naczelną rolę odgrywały w niej Kongregacje, mające jurysdykcję, wśród nich Kongregacja do Spraw Uniwersytetu Rzymskiego (Congregatio pro Universitate Studii Romani). Nazwa nie była jednak w pełni adekwatna, jednostka ta bowiem zajmowała się de facto wszystkimi ówczesnymi uniwersytetami.

Po okresie przejściowym, w którym wymieniona Kongregacja przestała funkcjonować, została powtórnie powołana do życia przez papieża Leona XIII w 1824 roku, Konstytucją apostolską Quod divina sapientia. Przybrała wówczas nazwę Kongregacji Studiów

\footnotetext{
${ }^{1}$ W. Góralski, Kardynał Zenon Grocholewski. Mąż Kościoła, Uczony, Nauczyciel, Duszpasterz, w: Świadectwo Słowa, red. G. Karolak, Ciechocinek 2008, s. 13-16; Tenże, Arcybiskup Prof. dr Zenon Grocholewski. Laudacja wygłoszona na cześć abp. dra Zenona Grocholewskiego, Prefekta Najwyższego Trybunału Sygnatury Apostolskiej, z okazji nadania mu tytułu doktora nauk prawnych "honoris causa” Akademii Teologii Katolickiej w Warszawie $w$ dniu 12 października 1998 r., Prawo Kanoniczne 41 (1998), nr 3-4, s. 4-5; Tenże, Opinia w sprawie wniosku o nadanie kard. Zenonowi Grocholewskiemu tytułu doktora honoris causa Uniwersytetu Ślaskiego w Katowicach, w: Kardynał Zenon Grocholewski, Doctor Honoris Causa Universitatis Silesiensis, Katowice 2010, s. 65-66; W. ŚwiątKiewicz, Promotoris laudatio, w: Kardynał Zenon Grocholewski, Doctor Honoris Causa Universitatis Silesiensis, s. 28-31; M. JęDraszewski, „Laudatio dedicata” a Sua Eminenza Rev. ma Zenon Card. Grocholewski, w: Quod iustum est et equum, red. M. Jędraszewski, J. Słowiński, Poznań 2013, s. 35-38.
} 
(Congregatio Studiorum). Zajmowała się ona uniwersytetami oraz wszystkimi szkołami publicznymi i prywatnymi Państwa Kościelnego, a po zniesieniu tegoż Państwa także uczelniami we Francji oraz papieskimi w Rzymie ${ }^{2}$.

W 1908 roku Pius X, Konstytucją apostolską Sapienti consilio dokonał nowej, znaczącej reformy Kurii Rzymskiej, potwierdzając istnienie i kompetencje Kongregacji Studiów. Z uwagi na brak dykasterii, która zajmowałaby się seminariami duchownymi, Benedykt XV, motu proprio Seminaria clericorum z 1915 roku ustanowił nową Kongregację, likwidując jednocześnie Kongregację Studiów. Jej dotychczasowe kompetencje zostały dodane do tej nowej Kongregacji, która otrzymała nazwę: Kongregacja do Spraw Seminariów i Uniwersytetów (Congregatio de Seminariis et Studiorum Universitatibus ${ }^{3}$.

Po Soborze Watykańskim II nastąpiła kolejna reforma Kurii Rzymskiej, dokonana przez Pawła VI Konstytucją apostolską Regimini Ecclesiae universae z $1967 \mathrm{roku}^{4}$. Kongregacja do Spraw Seminariów i Uniwersytetów zmieniła wówczas nazwę na: Kongregacja Wychowania Katolickiego (Congregatio pro Institutione Catholica). Dykasterii tej dodano jednocześnie kolejny, trzeci zakres kompetencji (poza seminariami duchownymi i uniwersytetami): dotyczący szkół.

W ramach dalszej reformy Kurii Rzymskiej, dokonanej przez Jana Pawła II Konstytucją apostolską Pastor bonus z roku 1988, mimo że przy wymienionej Kongregacji pozostały wszystkie trzy dotychczasowe kompetencje (seminaria, uniwersytety, szkoły), to jednak powrócono do dawnej nazwy (nieco zmienionej): Kongregacja do Spraw Seminariów i Instytutów Studiów (Congregatio de Seminariis atque Studiorum Insitutis). Jak zauważa Z. Grocholewski, chciano w ten sposób podkreślić, że w całej problematyce edukacji na pierwszym

${ }^{2}$ Z. Grocholewski, Kompetencje Kongregacji do Spraw Edukacji Katolickiej, w: Organizacja i funkcjonowanie administracji w Kościele, red. J. Krukowski, W. Kraiński, M. Sitarz, Toruń 2011, s. 8-9.

${ }^{3}$ Tamże, s. 8-9; Zob. także F. BĄczkowicz, Prawo kanoniczne. Podręcznik dla duchowieństwa, t. 1, Opole 1957, s. 464-465.

${ }^{4}$ Paulus VI, Constitutio apostolica "Regimini Ecclesiae universae” (15.08.1967), AAS 5(1967), s. 885-928. 
miejscu stawia się formację przyszłego duchowieństwa ${ }^{5}$. Ponieważ jednak po opublikowaniu wymienionej Konstytucji apostolskiej, w Kongregacji, o której mowa, niektórzy jej pracownicy postulowali powrót do poprzedniej nazwy ogólnej, czyli (Congregatio pro Insitutionae Catholica), Jan Paweł II ostatecznie wyraził na to zgodę, pod warunkiem dodania w nawiasie zwrotu: De Seminariis atque Studiorum Institutis, co oznaczało zaakcentowanie priorytetu spraw związanych z formacją seminarzystów. Ponadto Konstytucja apostolska zmieniła kolejność obszarów objętych kompetencją wymienionej dykasterii: na pierwszym miejscu znalazły się seminaria duchowne, na drugim szkoły, na trzecim zaś uniwersytety. Stolica Apostolska pragnęła w ten sposób podkreślić wagę wychowania podstawowego, jakim jest edukacja szkolna ${ }^{6}$.

W 2013 roku, na mocy motu proprio Benedykta XVI Ministrorum institutio dotychczasowe kompetencje Kongregacji Wychowania Katolickiego dotyczące seminariów duchownych zostały przeniesione do Kongregacji Duchowieństwa ${ }^{7}$.

Przy Kongregacji Wychowania Katolickiego istnieje Papieskie Dzieło Powołań Kapłańskich, której przewodniczącym jest prefekt Kongregacji, a wiceprzewodniczącym jej sekretarz. Poza tym prefekt Kongregacji jest z urzędu przewodniczącym dwóch Stałych Komisji Międzydykasterialnych: Do Spraw Formacji Kandydatów do Kapłaństwa oraz Do Spraw Równomiernego Rozmieszczenia Kapłanów $w$ Świecie.

W pracy Kongregacji Wychowania Katolickiego niezmiernie ważna jest współpraca $\mathrm{z}$ nuncjaturami apostolskimi oraz z dykasteriami Kurii Rzymskiej, najbardziej z Kongregacją Nauki Wiary, Kongregacją Duchowieństwa, Kongregacją Instytutów Życia Konsekrowanego i Stowarzyszeń Życia Apostolskiego oraz Kongregacją

\footnotetext{
${ }^{5}$ Z. Grocholewski, Kompetencje Kongregacji, s. 10.

${ }^{6}$ Tamże; Zob. także S. JAśKIEwICZ, Ukazywać światu Chrystusa. Wywiad z kardynałem Zenonem Grocholewskim, Poznań 2015, s. 79-90.

${ }^{7}$ Benedictus XVI, Motu proprio „Ministrorum institutio” (16.01.2013), AAS 105(2013), s. 136-139.
} 
Ewangelizacji Ludów, czyli Rozkrzewiania Wiary, a w niektórych kwestiach także z Sekretariatem Stanu. Bardzo ważne są także bezpośrednie i pośrednie kontakty z konferencjami episkopatów. Niemałe znaczenie dla pracy Kongregacji odgrywają też wizyty biskupów z całego świata ad limina Apostolorum. Liczy się wreszcie współpraca $\mathrm{z}$ różnymi organizacjami międzynarodowymi, jak UNESCO czy Rada Europejska ${ }^{8}$.

\section{Z Sygnatury do Kongregacji}

Opuszczenie - po 27. latach pełnego zaangażowania - Sygnatury Apostolskiej, a więc najwyższego hierarchicznie organu władzy sądowniczej w Kościele (a w określonym zakresie także administracyjnej) i przejście do Kongregacji Wychowania Katolickiego oznaczało przestawienie się przez nominata na zupełnie inny rodzaj pracy ${ }^{9}$. Wymieniona bowiem Kongregacja, nazywana również Kongregacją Edukacji Katolickiej, jedna z 9. kongregacji w Kurii Rzymskiej, wykonujących - w imieniu Ojca świętego - zadania czysto administracyjne (kongregacje można przyrównać do ministerstw w strukturach państwowych), ma za zadanie podejmowanie troski o formację kandydatów do kapłaństwa oraz upowszechnianie i rozwój formacji katolickiej w aspekcie ludzkim, duchowym, doktrynalnym i pastoralnym. Swoją działalność prowadziła w ramach trzech wydziałów: seminariów duchownych, uniwersytetów katolickich oraz szkół katolickich. Jak już wspomniano, w dniu 16 stycznia 2013 roku, na mocy decyzji Benedykta XVI seminaria duchowne zostały przyporządkowane Kongregacji Duchowieństwa ${ }^{10}$. Zarówno więc rodzaj spraw, jak i tryb ich załatwiania w Sygnaturze Apostolskiej i w Kongregacji Wychowania Katolickiego, znacznie różniące się między sobą, wymagały dość dużej wolty w podjęciu nowych zadań. Można powiedzieć, że te ostatnie stanowiły dla abp. Grocholewskiego rodzaj

\footnotetext{
${ }^{8}$ Z. Grocholewski, Kompetencje Kongregacji, s. 11-12.

${ }^{9}$ Zob. S. JAśkiewicz, Ukazywać światu Chrystusa, s. 79-80.

${ }^{10}$ Benedictus XVI, Motu proprio „Ministrorum institutio” (16.01.2013), AAS 105(2013), s. 136-139.
} 
nowego, szczególnego wyzwania. Z właściwą sobie determinacją podjął je zresztą natychmiast, i to z godnym podziwu rozmachem, który szybko przerodził się wręcz w entuzjazm. I jakkolwiek tak znakomite i sprawdzone przez lata umiejętności prawnicze, niezbędne w pracy pełnionej w organie sądowniczym najwyższego szczebla, nie były aż tak znaczące w posłudze przełożonego Kongregacji Wychowania Katolickiego, to jednak ta ostatnia funkcja wymagała $z$ kolei innych, niezbędnych do właściwego jej sprawowania, kwalifikacji. A właśnie w przypadku Zenona Grocholewskiego było tak, że spełniając, i to w sposób wyjątkowy, wszystkie wymogi stawiane prefektowi Sygnatury, legitymował się jednocześnie niezbędnymi kwalifikacjami do podjęcia urzędu prefekta Kongregacji Wychowania Katolickiego. Trzeba bowiem pamiętać, że wymieniony hierarcha był wówczas, i to od lat, cenionym mężem nauki i wybitnym nauczycielem akademickim (profesorem), doskonale znającym środowiska uczelniane, co - jak się okazało - pozwoliło mu szybko wejść in medias res nowej dykasterii kurialnej. Zazwyczaj zresztą nominacje na przełożonego Kongregacji Wychowania Katolickiego wystawiane są byłym profesorom uniwersyteckim. Nie bez znaczenia były tutaj również zdolności organizacyjne długoletniego sekretarza Sygnatury Apostolskiej ${ }^{11}$.

Rozpoczynając swoją działalność - jako szef „edukacji i szkolnictwa katolickiego" (obejmującego wszystkie szczeble) - nowy prefekt, wchodząc w dziedzictwo swojego wybitnego poprzednika (kard. Pio Laghiego), po dokładnym zorientowaniu się w tym, co do niego należy, energicznie zabrał się do dzieła. A obszar przyszłej posługi okazał się bardzo rozległy: rozsianych po całym świecie ponad 210 tysięcy szkół katolickich (z 50. milionami uczniów), 2000 wyższych uczelni (kościelnych i katolickich) i blisko 3700 seminariów duchownych, nie wspominając o trosce o dalszy rozwój szkolnictwa katolickiego, o rozwój i organizację formacji katolickiej oraz o kierowanie akcją powołań kapłańskich.

Po bliższym zapoznaniu się z arkanami funkcjonowania dykasterii oraz z poszczególnymi jej agendami, abp Grocholewski, korzystając z pomocy sekretarza i podsekretarza tejże Kongregacji, z dnia na

${ }^{11}$ W. Góralski, Kardynał Zenon Grocholewski, s. 19-20. 
dzień nie tylko poszerzał swoje rozeznanie w problematyce szeroko rozumianej edukacji w Kościele, lecz również podejmował coraz to nowe inicjatywy, m.in. w zakresie przygotowywania nowych dokumentów. Nie należy zapominać i o tym, że jako wybitny kanonista korzystał ze swojej bogatej wiedzy w tej dziedzinie, co i w nowej dykasterii kurialnej okazało się wielce pożyteczne.

Pełniony przez arcybiskupa Zenona urząd prefekta Kongregacji, podobnie zresztą jak sprawowany przezeń uprzednio urząd prefekta Sygnatury Apostolskiej - obydwa „kardynalskie” - zdawał się zapowiadać, że na najbliższym konsystorzu Ojciec święty powoła polskiego hierarchę do Kolegium Kardynalskiego. Tak też się stało, kiedy to w dniu 21 lutego 2001 roku papież Jan Paweł II mianował go (na konsystorzu) kardynałem, włączając do rzędu kardynałów diakonów i przydzielając mu kościół tytularny San Nicola in Carcere, położony w sercu starożytnego Rzymu, niedaleko znanego Teatro di Marcello. Nowo mianowany kardynał liczył wówczas 61 lat. Nominacja ta została przyjęta $z$ dużą radością i satysfakcją także w Polsce. W publicznym konsystorzu, podczas którego prefekt Kongregacji Wychowania Katolickiego otrzymał insygnia kardynalskie uczestniczyła m.in. trzyosobowa delegacja Uniwersytetu Kardynała Stefana Wyszyńskiego w Warszawie, która to uczelnia, a ściśle jej poprzedniczka (Akademia Teologii Katolickiej) dwa i pół roku wcześniej nadała abp. Grocholewskiemu doktorat honoris causa ${ }^{12}$.

Tymczasem posługa prefekta-kardynała w Kongregacji Wychowania Katolickiego nabierała coraz większej dynamiki, zwłaszcza gdy coraz częściej zaczął odwiedzać seminaria duchowne, uniwersytety i szkoły katolickie, rozsiane w różnych częściach świata, nawet w krajach o mniejszości katolickiej. Wizyty te służą pełniejszemu rozpoznaniu kondycji szkolnictwa kościelnego, szczególnie uniwersyteckiego, i nadania mu właściwego kształtu. Jako człowiek uniwersytetu, znajdował bez trudności wspólny język zarówno z rektorami i profesorami uczelni, jak i z ich studentami. A jako wybitny znawca

12 Tamże, s. 20. 
prawa kanonicznego i duszpasterz, usilnie zabiegał o właściwe miejsce i rolę szkół katolickich w dzisiejszym świecie ${ }^{13}$.

Chętnie kard. Zenon przyjmował także zaproszenia na różnego rodzaju kongresy i konferencje poświęcone problematyce edukacji w ogóle, a w szczególności edukacji katolickiej. W swoich wystąpieniach, które z reguły miały wówczas miejsce, dostojnik watykański przybliżał słuchaczom ideę wychowania katolickiego i chrześcijańskiego. Niejednokrotnie spotkania takie służyły ponadto nawiązywaniu przez przedstawiciela Watykanu dialogu ekumenicznego, co przysparza uznania Stolicy Apostolskiej. Niewątpliwie charyzmat niezwykłej komunikatywności prefekta Kongregacji Wychowania Katolickiego ułatwiał mu tego rodzaju kontakty, ubogacające obydwie strony. Podczas takich wizyt i spotkań nie zapominał nigdy o wymianie myśli z miejscowymi biskupami. Okazywał też żywe zainteresowanie działalnością seminariów duchownych.

Gdy chodzi o kontakty z biskupami, odpowiedzialnymi za dziedzinę wychowania katolickiego w swoich Kościołach partykularnych, to doskonałą okazją dla kard. Zenona były ciągłe wizyty tychże hierarchów z całego świata, składane przez nich (zazwyczaj w grupach regionalnych) w Kongregacji. Dobrym zwyczajem, jaki prefekt zaprowadził jest - poza tradycyjnym przekazywaniem im odpowiednich instrukcji, informacji i uwag - stworzenie możliwości stawiania przez nich pytań i podejmowania dyskusji ${ }^{14}$.

Wypada dodać, że kardynał - prefekt bardzo często z całą mocą podkreśla, że przyszłość Kościoła zależy przede wszystkim od dobrej formacji przyszłych kapłanów oraz od ilości i jakości szkół katolickich.

Nie od rzeczy będzie wspomnieć, że w okresie sprawowania przez kard. Grocholewskiego funkcji prefekta Kongregacji Wychowania Katolickiego powstało na różnych uniwersytetach szereg wydziałów teologicznych, w tym dwa w Polsce; na Uniwersytecie Mikołaja Kopernika w Toruniu i na Uniwersytecie Szczecińskim.

\footnotetext{
${ }^{13}$ Tamże.

${ }^{14}$ Tamże, s. $20-21$.
} 
Nie sposób wreszcie nie mieć świadomości, że piastowany przez Polaka urząd kurialny był w jego sprawowaniu niezwykle delikatny i odpowiedzialny, a tym samym trudny, a to z uwagi na tak liczne jednostki nauczania, które Mu podlegały, a także z uwagi na różnorodność systemów edukacyjnych, w których jednostki te funkcjonują ${ }^{15}$.

\section{Priorytet seminariów duchownych}

Kompetencja Kongregacji Wychowania Katolickiego dotycząca seminariów duchownych odnosi się jedynie do seminariów Kościoła łacińskiego, nie dotyczy natomiast Kościołów Wschodnich (mających własną specyfikę formacji przyszłego duchowieństwa). Gdy chodzi o seminaria instytutów życia konsekrowanego i stowarzyszeń życia apostolskiego oraz seminaria Kościołów lokalnych, które podlegają Kongregacji Ewangelizacji Narodów, to kompetencja Kongregacji Wychowania Katolickiego jest ograniczona jedynie do programu studiów, czyli do wymiaru intelektualno-teologicznego.

Za seminaria duchowne odpowiedzialni są przede wszystkim biskupi diecezjalni, rola Kongregacji ogranicza się do promocji seminariów, niesienia im pomocy oraz sprawowania nadzoru nad nimi, zwłaszcza gdy chodzi o przestrzeganie norm Kodeksu Prawa Kanonicznego (kann. 232-264), stosownie do wskazówek Adhortacji apostolskiej Jana Pawła II Pastores dabo vobis z 1992 roku $^{16}$. Zgodnie z art. 113, \$\$ 1-2 tego dokumentu, nadzór Kongregacji dotyczy takich elementów jak: zakładanie seminariów, ich kierownictwo, wszystkie aspekty formacji, życie wspólne, kwalifikacje i zadania formatorów i wykładowców.

Jedną z niełatwych i złożonych zadań Kongregacji w stosunku do seminariów duchownych są wizytacje apostolskie, które od czasu do czasu odbywane są w poszczególnych krajach. Wizytacje te wiążą się m.in. z wnikliwym analizowaniem w Kongregacji stosownych

\footnotetext{
${ }^{15}$ Tamże, s. 21.

${ }^{16}$ Jan Pawe€ II, Adhortacja apostolska „Pastorem dabo Vobis” (29.03.1992), „L'Osservatore Romano”, wyd. Polskie 13 (1992), nr 3-4, s. 1-63; Zob. Z. GrochoLEWSKI, Życie duchowe - centrum formacji kapłańskiej w nauczaniu Jana Pawła II, Wrocław 2010.
} 
relacji przesyłanych uprzednio przez seminaria. Do poszczególnych relacji wymieniona dykasteria przygotowuje z kolei odpowiednie uwagi, kierując je następnie do biskupów, jak również do Konferencji Biskupów jako takiej, starając się ją poinformować o spostrzeżeniach w skali całego kraju ${ }^{17}$.

Zadaniem Kongregacji jest następnie wydawanie potrzebnych dokumentów służących biskupom diecezjalnym w dziele formacji seminaryjnej. W okresie kierowania dykasterią przez kard. Z. Grocholewskiego wydała ona szereg ważnych aktów prawnych, m.in. odnośnie do nieprawidłowości i innych przeszkód do przyjęcia i wykonywania święceń (1999), osób z tendencjami homoseksualnymi w perspektywie ich przyjęcia do seminarium duchownego i dopuszczenia do święceń (2005), formacji przyszłych kapłanów w dziedzinie duszpasterstwa emigrantów (2005), korzystania z kompetencji nauk psychologicznych w przyjmowaniu do seminarium duchownego i formacji kandydatów do kapłaństwa (2008), reformy studiów kościelnych filozofii (2011). Kongregacja pracuje nad kolejnymi dokumentami, dotyczącymi m.in. roli internetu w formacji seminaryjnej, oraz nad nową Ratio fundamentalis institutionis sacerdotalis (uwzględni dokumenty wydane po roku 1985 i weźmie pod uwagę sytuację aktualną).

Spośród wymienionych dokumentów, na kształt których znaczący wpływ miał kard. Grocholewski, sam purpurat wskazuje dwa: 1) Instrukcja w sprawie kryteriów rozeznania powołania osób $\mathrm{z}$ tendencjami homoseksualnymi w perspektywie ich przyjęcia do seminarium i dopuszczenia do święcen ${ }^{18}$; 2) Wskazania w sprawie korzystania z kompetencji psychologicznych w przyjęciu do seminarium

\footnotetext{
${ }^{17}$ Z. GrocholewsKi, Kompetencje Kongregacji, s. 14.

${ }^{18}$ Istruzione circa i criteri di discernimento vocazionale riguardo alle persone con tendenze omosessuali in vista della loro ammissione al Seminario e agli Ordini sacri (4 novembre 2005).
} 
i w formacji kandydatów do kapłaństwa ${ }^{19}$. Obydwa spotkały się z bardzo dużym zainteresowaniem i zarazem powszechnym uznaniem ${ }^{20}$.

Do obszaru zagadnień poruszanych w Kongregacji pod kierownictwem jej doświadczonego prefekta należą także seminaria międzydiecezjalne. Zgodnie z kan. $237 \$ 2 \mathrm{KPK}$, aby takie seminarium mogło powstać, konieczna jest wcześniejsza aprobata Stolicy Apostolskiej (Kongregacji Wychowania Katolickiego), dotycząca zarówno erygowania seminarium jak i jego statutów ${ }^{21}$.

Sekcja Seminariów Duchownych w Kongregacji zajmuje się także „kolegiami” w Wiecznym Mieście - zarówno tymi, które są prawdziwymi seminariami, jak i tymi, w których mieszkają kapłani studiujący w Rzymie. Kongregacja jest tutaj kompetentna w sprawie aprobaty statutów takich kolegiów, mianowania ich rektorów oraz nadzoru nad ich funkcjonowaniem ${ }^{22}$.

Kard. Z. Grocholewski, kierując Kongregacją poświęcał bardzo dużo uwagi seminariom duchownym, twierdząc, że przede wszystkim

${ }^{19}$ Orientamenti per l'utilizzo delle competenze psicologiche nell'ammissione e nella formazione dei candidati al sacerdozio (28 giugno 2008).

${ }^{20}$ Stwierdzenie kard. Zenona Grocholewskiego w rozmowie z ks. Wojciechem Góralskim dnia 27 maja 2015 roku.

${ }^{21}$ Dla uniknięcia nieporozumień kard. Z. Grocholewski wyjaśnia, że z seminarium międzydiecezjalne we właściwym tego słowa znaczeniu powstaje przy współpracy kilku biskupów, gdy wszyscy oni czują się odpowiedzialni za tę instytucję i nią kierują, choć bezpośrednie zwierzchnictwo zleca się często jednemu z nich. Inna jest natomiast sytuacja, gdy jakieś wyróżniające się seminarium (często w siedzibie metropolii), kierowane przez własnego biskupa, przyjmuje i kształci także seminarzystów z innych diecezji, niebędących w stanie utworzyć własnego seminarium. $\mathrm{W}$ takim przypadku mamy do czynienia z seminarium diecezjalnym, które przyjmuje także alumnów z innej czy z innych diecezji. Doświadczenie uczy, że to drugie rozwiązanie często funkcjonuje lepiej niż seminarium międzydiecezjalne. Jeżeli bowiem jest kilku odpowiedzialnych za tę samą jednostkę formacyjną, a każdy z nich, ma nieco inną wizję kształcenia przyszłych duchownych, wówczas niejednokrotnie trudno jest dojść do porozumienia w różnych określonych aspektach programu, ze szkodą dla samej formacji. Natomiast jeśli jest tylko jeden biskup odpowiedzialny za seminarium, jego profil jest bardziej przejrzysty. Zob. Kompetencje Kongregacji, s. $15-16$.

${ }^{22}$ Tamże, s. 16. 
od należnego przygotowania przyszłych duchownych w dużej mierze zależeć będzie przyszłość Kościoła. Wiele z tych seminariów istniejących na różnych kontynentach odwiedził, wygłaszając z tej okazji referaty. Wymowne jest jego następujące wyznanie, które najlepiej zdaje się uzasadniać przyznanie w pracach Kongregacji priorytetu seminariom duchownym: „Nie ma nic piękniejszego, jak dawać Pana Boga, jak dawać Chrystusa ludziom, ubogacać ich największym dobrem”23.

\section{Wokół szkół katolickich}

Kompetencje Kongregacji Wychowania Katolickiego w odniesieniu do szkół katolickich nie obejmują Kościołów Wschodnich oraz terenów misyjnych, natomiast dotyczą szkół prowadzonych przez instytuty życia konsekrowanego i stowarzyszenia życia apostolskiego.

Art. 114 Konstytucji apostolskiej Jana Pawła II Pastor bonus zlecił Kongregacji Wychowania Katolickiego troskę o to, by fundamentalne zasady dotyczące wychowania katolickiego były coraz bardziej pogłębiane, bronione i poznawane przez wiernych; by wierni mogli wypełniać swoje obowiązki w tej dziedzinie, i aby społeczność świecka uznawała te prawa i chroniła je. Kard. Grocholewski nie ma cienia wątpliwości, że dyspozycja ta „w sposób szczególny odnosi się do szkół”24. Wyraża jednocześnie przekonanie, że „trudno przecenić znaczenie i rolę szkół katolickich"25. Podkreśla też, że cieszą się one wszędzie dużym uznaniem. Są kraje, jak stwierdza, w których więcej jest uczniów w szkołach katolickich, niż samych katolików. Kardynał jest dumny ze szkół katolickich, zwłaszcza tych działających w krajach i regionach bardzo biednych, umożliwiających naukę dzieciom i młodzieży, która inaczej nie miałaby żadnych szans na edukację. Odwiedził także, jak mówi w wywiadzie, szkoły katolickie,

\footnotetext{
${ }^{23}$ Wywiad kard. Zenona Grocholewskiego udzielony redakcji czasopisma „Przedświt” [brak daty], w: Świadectwo Słowa, s. 119.

${ }^{24}$ Tamże, s. 17.

25 Tamże.
} 
w których uczniów - katolików jest tylko znikomy procent, i w których był przyjmowany z entuzjazmem ${ }^{26}$.

„Zostawszy prefektem Kongregacji, wyznaje kardynał, byłem zaskoczony faktem, że szkoła katolicka wszędzie, naprawdę wszędzie, cieszy się ogromnym uznaniem" ${ }^{27}$. Jako przykład wskazuje tutaj m.in. odwiedzoną przez siebie Tajlandię, która jest krajem buddyjskim (monarchią buddyjską), gdzie buddyści stanowią niemal 95\% społeczeństwa; katolików jest tam zaledwie około 300 tysięcy. Do szkół katolickich uczęszcza tam aż 465 tysięcy uczniów. Odwiedzając w tym kraju dwie szkoły (jedna liczyła ok. 2,5 tysiąca uczniów, druga zaś około 6 tysięcy) skonstatował, że w tej pierwszej katolików było jedynie ok. 300, wszyscy inni byli buddystami.

Jako inny przykład podaje Indonezję i stwierdza, że w tym największym kraju muzułmańskim jest bardzo dużo szkół katolickich (także wyższych uczelni katolickich), do których uczęszczają muzułmanie. Gdy kilka lat temu ambasador tego kraju przy Watykanie, muzułmanin, odwiedził kard. Zenona, bardzo pochlebnie wyrażał się o szkołach katolickich, sam zresztą, podobnie jak jego rodzice, ukończył jedną z nich ${ }^{28}$.

„Niedawno, czytamy w relacji ks. kardynała, odwiedziłem szkołę wśród slumsów w Nairobi (Kenia). Dotarliśmy do niej idąc zaułkami, pełnymi ścieków, brudu, wśród biednych lepianek. Warunki naprawdę nędzne, ciasnota, choć witały nas dzieci radosne, o inteligentnych twarzach. Na małym podwórzu szkolnym popisały się występami. Żadne z tych dzieci nie miałoby możliwości zdobycia nawet podstawowego wykształcenia, gdyby się nimi nie zajęli bracia zakonni, prowadzący tą szkołę"29.

\footnotetext{
${ }^{26}$ Wywiad kard. Zenona Grocholewskiego udzielony ks. Wojciechowi Góralskiemu 29 maja 2015 roku.

${ }^{27}$ Z. Grocholewski, Kompetencje Kongregacji, s. 19; Zob. S. JAśKiewicz, Ukazywać światu Chrystusa, s. 88-90.

${ }^{28}$ Tamże.

${ }^{29}$ Tamże, s. 20.
} 
Sprawującemu pieczę nad szkolnictwem katolickim w świecie kard. Zenonowi przyświeca idea właściwego wychowania młodego człowieka. „W szkole katolickiej, powie w jednym z wywiadów, chodzi o integralne wychowanie człowieka. Nie tylko o to, by przekazać informacje, ale by wychować odpowiedzialnego człowieka, który te wiadomości mógłby wykorzystać do dobra, nie do zła"30. A innym razem powie: „My robimy wszystko, aby szkoła katolicka naprawdę przekazywała to, co jest jej bogactwem i sensem jej istnienia"31.

Bolączką Kongregacji i jej prefekta jest to, że w niektórych szkołach katolickich nie w pełni hołduje się katolickim wartościom. Tak np. w Belgii i Holandii, gdzie ok. 60\% wszystkich dzieci uczęszcza do szkół katolickich, szkoły te prezentują wprawdzie dobry poziom nauczania, lecz nie przekazują katolickich wartości, co budzi niepokój rodziców. Nic też dziwnego, że Kongregacja popiera organizację międzynarodową rodziców szkół katolickich, którzy bronią ich prawa do tego, by szkoła katolicka odpowiednio przekazywała wartości katolickie ich dzieciom. Niepokoi także tendencja do relatywizowania tychże wartości w niektórych szkołach katolickich w Azji ${ }^{32}$.

Niejednokrotnie kardynał-prefekt wskazywał na niepokojące trudności, przed którymi stają wychowawcy katoliccy - takie, jak: negacja wychowania tradycyjnego, problemy dotyczące osobowości szkoły, kryzys rodziny, niewystarczające współdziałanie środowisk wychowawczych, relatywizm moralny, zatracanie sensu wychowania u wychowawców, sprowadzanie wychowania do nauczania, czy „mediatyzacja” życia ${ }^{33}$. Znaczący wydaje się postulat Z. Grocholewskiego dotyczący potrzeby odpowiedniej formacji (intelektualnej i duchowej) samych nauczycieli ${ }^{34}$.

\footnotetext{
${ }^{30}$ Umysł otwarty na wiedzę, serce - na dobro. Z księdzem kardynałem Zenonem Grocholewskim, prefektem Watykańskiej Kongregacji ds. Wychowania Katolickiego, rozmawia o. Jacek Cydzik, w: Świadectwo Słowa, s. 127.

${ }^{31}$ W. Świątkiewicz, Promotoris laudatio, s. 37.

${ }^{32}$ Z. Grocholewsi, Kompetencje Kongregacji, s. 20-21.

${ }^{33}$ Zob. J. MAstalski, Sfide contemporanee dell'educazione cristiana (prospettiva pedagogica del Cardinale Z. Grocholewski), w: Quod iustum est et equum, s. 453-454.

${ }^{34}$ Tamże, s. 457.
} 
W okresie pełnienia przez polskiego kardynała funkcji prefekta Kongregacji Wychowania Katolickiego ta ostatnia wydała wiele znaczących dokumentów w przedmiocie szkolnictwa katolickiego. Trzy z nich, stanowiące pewną całość, są szczególnie bliskie purpuratowi, spotkały się one zresztą z dużym uznaniem zainteresowanych. Pierwszy z nich (przygotowany jeszcze za kard. Pio Laghiego) dotyczy wiernych świeckich jako świadków wiary w szkole (1982), drugi osób konsekrowanych i ich misji w szkole (2002), trzeci natomiast nosi znamienny tytuł: „Wychowywać razem w szkole katolickiej. Misja dzielona przez osoby konsekrowane i wiernych świeckich” (2007). Chodzi w nim o problem związany ze zjawiskiem zmniejszenia się liczby powołań zakonnych, a tym samym $z$ deficytem osób zakonnych w szkołach prowadzonych przez zakony, co skutkowało tendencją do wycofywania się tychże osób ze szkół i przekazywania ich osobom świeckim. Tymczasem Kongregacja zaczęła w tej sytuacji raczej promować współpracę osób zakonnych z wiernymi świeckimi w prowadzeniu szkół katolickich. Na takiej współpracy szkoły jedynie zyskują, i to z wielu względów. Z innych dokumentów wypracowanych pod okiem prefekta - Polaka można wymienić list o nauczaniu religii w szkołach (2009) oraz dokument na temat dialogu międzykulturowego w szkole katolickiej (2013), będący owocem konferencji naukowej zorganizowanej przez Kongregację ${ }^{35}$.

Dużą pomoc w pracy Kongregacji na polu szkolnictwa katolickiego stanowi jej współpraca z organizacjami międzynarodowymi. Głównie chodzi o organizacje międzynarodowe, nie rządowe, a jest ich wiele. Najbardziej znane to OIEC (Office International pour l'Enseignement Catholique), z siedzibą w Brukseli; jego niejako sekcja europejska CEEC (Comité Européen pour l'Enseignement Catholique); UMEC (Union Mondiale Enseignantes Catholiques); czy bardzo aktywne OMAEC (Organisation Mondial de Anciens et Anciennes Elèves de l'Enseignement Catholique).

Dykasteria utrzymuje także kontakty z siedzibą Międzynarodowych Organizacji Katolickich w Genewie. Śledzi również prace

\footnotetext{
${ }^{35}$ Z. Grocholewski, Kompetencje Kongregacji, s. 18.
} 
organizacji międzynarodowych: głównie Organizacji Narodów Zjednoczonych, UNESCO, Rady Europejskkiej, także Unii Europejskiej, choć Stolica Apostolska jest tylko „obserwatorem” w tych organizacjach. Warto w tym miejscu dodać, że w siedzibie UNESCO w Paryżu kard. Grocholewski wygłosił konferencję (przewodniczył jej muzułmanin) na temat wymiaru miłości w nauczaniu szkolnym ${ }^{36}$.

\section{Troska o wyższe uczelnie kościelne i katolickie}

Zakres kompetencji Kongregacji Wychowania Katolickiego w przedmiocie wyższych uczelni kościelnych i katolickich nie jest ograniczony przez żadną inną dykasterię kurialną, obejmuje więc także jednostki Kościołów wschodnich, tereny misyjne oraz instytuty życia konsekrowanego i stowarzyszenia życia apostolskiego.

Gdy chodzi o uczelnie kościelne ${ }^{37}$, a więc te, które opierają swoje badania i nauczanie na Objawieniu oraz łączą się ściśle z misją Kościoła (teologia, prawo kanoniczne, historia Kościoła, filozofia chrześcijańska, wychowanie chrześcijańskie, itp.), to podstawowym aktem normatywnym jest dla nich Konstytucja apostolska Jana Pawła II Sapientia christiana z 1979 roku $^{38}$. Mogą one być zakładane lub ewentualnie aprobowane przez Kongregację Wychowania Katolickiego. Do dykasterii tej należy również zatwierdzanie statutów i programów studiów tych uczelni, podobnie jak ich rektorów; każdy zaś ich stały

${ }^{36}$ Gdy chodzi o kwestie prawne związane ze szkolnictwem katolickim, zob. Z. Grocholewski, Współdziałanie Kościoła i szkoły w realizacji misji wychowania - doświadczenia i perspektywy z punktu widzenie Stolicy Apostolskie, w: Ochrona funkcji wychowawczej rodziny, red. J. Krukowski, A. Maćkowski, Szczecin 2007, s. 129-153; Tenże, Szkoła katolicka według Kodeksu Prawa Kanonicznego, w: Finis legis Christus. Księga pamiątkowa dedykowana ks. prof. Wojciechowi Góralskiemu z okazji siedemdziesiątej rocznicy urodzin, red. J. Wroceński, J. Krajczyński, Warszawa 2009, tom 1, s. 141-152.

${ }^{37}$ Uczelnie kościelne obejmują 7 uniwersytetów, ok. 360 wydziałów, ok. 350 instytutów akademickich afiliowanych do wydziałów kościelnych, 25 instytutów agregowanych i 12 włączonych do tychże wydziałów. Zob. W. Świątkiewicz, Promotoris laudatio, s. 38.

${ }^{38}$ Ioannes Paulus II, Constitutio apostolica,,Sapientia christiana” (15.04.1979), AAS 71(1979), s. 469-499. 
profesor winien posiadać nihil obstat, by mógł zostać mianowany (rocznie wydawanych jest ok. 600 tego rodzaju zezwoleń, poprzedzonych stosownym dochodzeniem). W zakresie tym Kongregacja współpracuje bardzo ściśle z Kongregacją Nauki Wiary a także Sekretariatem Stanu ${ }^{39}$.

W okresie sprawowania przez kard. Grocholewskiego urzędu prefekta Kongregacja wydała kilka dokumentów adresowanych do wydziałów kościelnych, m.in. o nauczania prawa kanonicznego (2002), globalizacji szkolnictwa wyższego (2003), wyższych instytutach wiedzy religijnej (2008) czy wspomnianej już wyżej reformie studiów filozoficznych (2011).

O tym, jak w mniemaniu kardynała-prefekta trudno jest przecenić rolę uczelni kościelnych, przekonuje m.in. jego następujące stwierdzenie: „Wydział teologiczny jest ubogaceniem dla uniwersytetu” ${ }^{40}$.

Co się tyczy z kolei uczelni katolickich, to przedmiotem studiów i nauczania mogą być wszystkie dziedziny nauki, a więc te, które wykładane są także na innych uniwersytetach (np. medycyna, dyplomacja, inżynieria., itd.). Podstawowym dokumentem normatywnym dla tych uczelni jest Konstytucja apostolska Jana Pawła II Ex corde Ecclesiae, wydana w 1990 roku $^{41}$. Zaangażowanie Kongregacji w sprawy poszczególnych tego rodzaju uczelni jest znacznie mniejsze. Zgodnie bowiem z powołaną Konstytucją apostolską, uniwersytety i inne uczelnie katolickie niekonieczne muszą być zakładane czy zatwierdzane przez tę dykasterię, lecz mogą być erygowane także przez Konferencje Biskupów, poszczególnych biskupów diecezjalnych, instytuty zakonne, stowarzyszenia życia apostolskiego, jak również przez wiernych świeckich. By mogły jednak nazywać się katolickimi, powinny uzyskać na to zgodę kompetentnej władzy kościelnej (kan. $803 \$ 3 \mathrm{KPK}$ ). Na całym świecie funkcjonuje w sumie ponad 1500 wyższych uczelni katolickich, natomiast zatwierdzonych

\footnotetext{
${ }^{39}$ Z. Grocholewski, Kompetencje Kongregacji, s. 22-23.

${ }^{40}$ Umysł otwarty na wiedze, s. 132.

${ }^{41}$ IoAnnes Paulus II, Constitutio apostolica „Ex corde Ecclesiae”(15.08.1990), AAS 82(1990), s. 1475-1509.
} 
przez Stolicę Apostolską jest jedynie ok. 50. Ze zrozumiałych względów Kongregacja jest bezpośrednio zaangażowana w stosunku do tych ostatnich. Jej kompetencje rozciągają się jednak na wszystkie uniwersytety katolickie ${ }^{42}$.

Trosce kard. Zenona o uniwersytety katolickie towarzyszy pragnienie, by były to uczelnie solidne. „Jeśli w naszej Kongregacji, stwierdza w jednym z wywiadów, zajmujemy się uniwersytetami katolickimi, to staramy się, żeby ten uniwersytet miał dwa wymiary: solidny uniwersytet $\mathrm{z}$ punktu widzenia naukowego, i żeby był to solidny wymiar katolicki" ${ }^{\prime 3}$.

Przedmiotem troski Kongregacji jest także współpraca między uczelniami katolickimi, a także szerokie relacje uniwersytetów i innych uczelni katolickich z innymi uczelniami państwowymi czy prywatnymi ${ }^{44}$.

Pod okiem prefekta Kongregacja zabiega ponadto o żywe kontakty $\mathrm{z}$ różnymi organizacjami międzynarodowymi uniwersytetów katolickich. Najbardziej znana jest tutaj FIUC/IFCU (Fédération Internationale des Universités Catholiques / International Federation of Catholic Universities), o wymiarze światowym, utworzona przez papieża Piusa XII w 1950 roku. W okresie pełnienia urzędu prefekta Kongregacji przez kard. Zenona Grocholewskiego współpraca ta bardzo się zacieśniła, m.in. poprzez wspólnie organizowane sympozja i konferencje naukowe ${ }^{45}$.

Praca prefekta wymienionej dykasterii kurialnej wiąże się także z rozwiązywaniem różnorodnych trudności. Uczelnie kościelne i katolickie funkcjonują bowiem w bardzo zróżnicowanych warunkach i prezentują różny poziom nauczania; borykają się też niekiedy z przeciwnościami pochodzącymi ab extra. Cieszy go jednak to, że

\footnotetext{
${ }^{42}$ Z. Grocholewski, Kompetencje Kongregacji, s. 24-25.

${ }^{43}$ Mediom potrzebni sq ludzie prawdy. Z J.Em. ks. kard. Zenonem Grocholewskim rozmawia o. Grzegorz Maj CSRS, w: Świadectwo Słowa, s. 122.

${ }^{44}$ Tamże, s. 25.

${ }^{45}$ Wywiad kard. Zenona Grocholewskiego udzielony ks. Wojciechowi Góralskiemu 29 maja 2015 roku.
} 
instytucje te powstają w coraz to nowych częściach świata. Tak np. w Indonezji, największym kraju muzułmańskim, działa aż 46 wyższych uczelni katolickich. Dużo dobrych i ciągle się rozwijających wyższych uczelni działa w Ameryce Łacińskiej, a w stolicy Chile uniwersytet zwany popularnie La Pontificia jest niewątpliwie przodującym. Nie trzeba dodawać, że w ciągu blisko szesnastu lat kierowania Kongregacją, kardynał - prefekt odwiedził liczne uczelnie kościelne i katolickie na wszystkich kontynentach ${ }^{46}$. Mówi o tych wizytach z wielkim entuzjazmem, a w swoich publikacjach poświęca im dużo uwagi, przypisuje przy tym duże znaczenie tym uczelniom i zachęca do ich tworzenia. Brał też udział w wielu kongresach i sympozjach międzynarodowych uniwersytetów katolickich w różnych częściach świata. Wzmocnił współpracę Kongregacji w różnego rodzaju stowarzyszeniami uniwersytetów katolickich. W 2005 dykasteria wydała Indeks: Universitates et alia Instituta Studiorum Superiorum Ecclesiae catholicae (2005); obecnie opracowywane jest nowe wydanie, bardziej kompletne.

Nie sposób nie wspomnieć o wkładzie kard. Grocholewskiego we wzmocnienie, zreformowanie i zagwarantowanie podstaw materialnych Papieskiemu Instytutowi Studiów Arabskich i Islamistyki, o doniosłym dzisiaj znaczeniu, której to instytucji jest wielkim kanclerzem. W styczniu 2015 roku Kongregacja wraz z tym Instytutem zorganizowała trzydniową konferencję nt. „Studying and Understanding the Religion of the Other", $\mathrm{z}$ udziałem przedstawicieli muzułmanów.

Najważniejszą jednak zasługą kard. Grocholewskiego jest niewątpliwie dowartościowanie studiów kościelnych (abstrahując od uniwersytetów katolickich) na forum międzynarodowym. Ponieważ wyższe uczelnie kościelne nadają stopnie i tytuły naukowe w imieniu Stolicy Apostolskiej, są one w ścisłym tego znaczeniu uczelniami Stolicy Apostolskiej. Dlatego też właśnie Stolica Apostolska, którą w tej dziedzinie reprezentuje Kongregacja Wychowania Katolickiego, przystąpiła w 2003 roku jako członek do tzw. procesu bolońskiego, który zmierza głównie do promowania studiów wyższych w Europie,

${ }^{46}$ Zob. Z. Grocholewski, Kompetencje Kongregacji, s. 25. 
jak i wypracowania wspólnych kryteriów w celu wzajemnego uznawania stopni i tytułów akademickich. Stolica Apostolska przystąpiła do tego procesu jako dysponent wielu uczelni kościelnych ${ }^{47}$. To zaś sytuuje studia ecclesiastica wewnątrz całokształtu problematyki studiów w Europie, dowartościowuje stopnie i tytuły naukowe z zakresu teologii i innych dziedzin studiów kościelnych, pozwalając im równocześnie zachować własną, specyficzną tożsamość. Ponadto umożliwia to obecność Stolicy Apostolskiej w instytucjach, w których są podejmowane decyzje w sprawach studiów wyższych (spotkania ministrów edukacji, forum UNESCO, itp.), oraz wnoszenie na tym poziomie własnego wkładu ${ }^{48}$.

W związku z tym Kongregacja przyczyniła się do powstania - decyzją Ojca świętego Benedykta XVI z dnia 19 września 2007 roku Agenzia della Santa Sede per la Valutazione e la Promozione della Qualità delle Università e Facoltà Ecclesiastiche, do której to instytucji powołano także osoby spoza sfer kościelnych (m.in. z UNESCO i z Rady Europejskiej). By pomóc wydziałom kościelnym w dostosowaniu się do wymogów procesu bolońskiego, Kongregacja utworzyła Komisję Międzynarodową, która spotyka się okresowo i studiuje zaistniałe problemy (wydała już 8 okólników). Następnie przygotowała pewnego rodzaju vademecum zatytułowane: La Cultura della Qualità. Guida per le Facoltà Ecclesiastiche (Libreria Editrice Vaticana 2011), opublikowane także po angielsku: Quality Culture. A Handbook for Ecclesiastical Faculties (Libreria Editrice Vaticana 2012). Wreszcie doskonali już specjalne sito-web, na którym będą zamieszczone wszystkie informacje w tym względzie.

Bardzo dużym uznaniem i równocześnie uczestnictwem szerokiego wachlarza środowisk naukowych i władz państwowych cieszył się kongres zorganizowany w Watykanie przez Kongregację razem z UNESCO na temat procesu bolońskiego w 2006 roku, którego

\footnotetext{
${ }^{47}$ Gdy chodzi o proces boloński, to uniwersytety katolickie muszą się kierować prawem państw, w których istnieją.

${ }^{48}$ Wywiad kard. Zenona Grocholewskiego udzielony ks. Wojciechowi Góralskiemu 29 maja 2015 roku.
} 
dokumentację wydała zarówno Kongregacja (w językach, w jakich zostały wygłoszone przedłożenia), jak i UNESCO (w języku angielskim).

Nawiązano też w tym czasie kontakty z innymi organizacjami międzynarodowymi na różnych kontynentach oraz z poszczególnymi rządami państw, w celu zapewnienia uznawania stopni i tytułów naukowych i możliwości wyrażenia myśli Kościoła oraz wnoszenia własnego wkładu w dziedzinie studiów wyższych ${ }^{49}$.

Z okazji 50-lecia soborowej Deklaracji Gravissimum educationis na temat wychowania katolickiego oraz 25-lecia Konstytucji apostolskiej Jana Pawła II Ex corde Ecclesiae dotyczącej uniwersytetów katolickich, Kongregacja, pod kierownictwem kard. Grocholewskiego, w maju 2015 roku zorganizowała na ten temat forum w siedzibie UNESCO w Paryżu oraz zapowiedziała na listopad (18-21) tegoż roku światowy kongres z udziałem kilku tysięcy osób. By dobrze przygotować to ostatnie spotkanie, w kwietniu ubiegłego roku wydała Instrumentum laboris: Educare oggi e domani. Una passione che si rinnova, wysyłając ten dokument do wszystkich zainteresowanych. Przedstawiła w nim wyzwania, jakie stawia obecnie edukacja, i postawiła różne pytania z prośbą o odpowiedź. Dokument ten spotkał się z bardzo wieloma pochwałami, a Kongregacja otrzymała tysiące odpowiedzi, które są obecnie przedmiotem studium, by wyniki tych konsultacji przedstawić podczas listopadowego kongresu; natomiast po obradach kongresowych odpowiedzi te staną się podstawą do opracowania odpowiedniego dokumentu ${ }^{50}$.

\section{Zakończenie}

Przedstawiony najzwięźlej wkład kard. Zenona Grocholewskiego, duszpasterza, uczonego, nauczyciela, bliskiego współpracownika czterech papieży, jednego z najwybitniejszych mężów Kościoła przełomu stuleci, w dzieło edukacji katolickiej w świecie jednoznacznie wskazuje, iż sprawa wychowania człowieka głęboko leży mu na sercu. Doskonale rozumiejąc, że wychowanie to wciąż pozostaje

\footnotetext{
${ }^{49}$ Tamże.

50 Tamże.
} 
fundamentalnym zadaniem ludzkości, oraz mając głęboką świadomość roli, jaką ma do spełnienia w tym dziele Kościół, zasłużony prefekt Kongregacji Wychowania Katolickiego stał się wyjątkowym promotorem wielorakich działań na polu edukacji i gorliwym rzecznikiem idei integralnego rozwoju człowieka. Jego sięgająca blisko szesnastu lat kompetentna i naznaczona pełnym zaangażowaniem posługa w wymienionej dykasterii Kurii Rzymskiej okazała się godnym uznania ciągiem działań, które zmierzały do urzeczywistniania owego podstawowego zadania ludzkości. Doskonałe zaś rozeznanie w przemianach zachodzących w dobie zglobalizowanej kultury pozwoliło mu na stawianie trafnych diagnoz w obieraniu kierunku działania.

Hołując zasadzie konieczności integracji wartości naturalnych z nadprzyrodzonymi, a tym samym ścisłego powiązania wychowania ludzkiego i chrześcijańskiego, honorowany dziś purpurat swoją aktywność na stanowisku prefekta tej znaczącej Kongregacji urzeczywistniał - stosownie do wskazań soborowej Deklaracji Gravissimum educationis - $\mathrm{w}$ harmonijnym współdziałaniu $\mathrm{z}$ innymi czynnikami odpowiedzialnymi za wychowanie. W szczególności należy tu podkreślić przysparzającą Kościołowi uznania partnerską współpracę kard. Zenona $\mathrm{z}$ instytucjami i organizacjami państwowymi i międzynarodowymi.

Znamienne jest i to, że akcentując powszechne prawo do wychowania chrześcijańskiego, dawny wychowanek, a potem profesor $\mathrm{Pa}$ pieskiego Uniwersytetu Gregoriańskiego raz po raz dawał wyraz temu, że wychowanie to zmierza nie tylko do pełnego rozwoju osoby ludzkiej, lecz przede wszystkim ma na uwadze to, by ochrzczeni, wprowadzani stopniowo $\mathrm{w}$ tajemnicę zbawienia, stawali się z każdym dniem coraz bardziej świadomi otrzymanego daru wiary i pomagali w chrześcijańskim budowaniu świata.

Troska wieloletniego prefekta znaczącej dykasterii kurialnej obejmuje wszystkie trzy obszary jej kompetencji: seminaria duchowne, szkoły katolickie oraz wyższe uczelnie kościelne i katolickie. W każdym $z$ nich nietrudno dostrzec jego pełne zaangażowanie, właściwą mu dynamikę działania, znajomość problematyki, poszanowanie 
wolności religijnej, umiejętność nawiązywania współpracy z każdym środowiskiem, szerokie otwarcie na dialog ze wszystkimi.

W pełnionej z wyjątkowym oddaniem pracy kard. Zenona Grocholewskiego na specjalną uwagę zasługują liczne wizyty podejmowane w różnych krajach i częściach świata, służące rozeznaniu sytuacji szkolnictwa kościelnego (różnych stopni) i nadaniu mu właściwego kształtu oraz najwyższych standardów jakości kształcenia. Wieloletni profesor uczelni rzymskich okazał się tutaj prawdziwym promotorem szkół katolickich, podobnie jak gorącym rzecznikiem uczelni kościelnych i katolickich. Z ogromną energią zabiegał przy tym o właściwe miejsce i rolę tych placówek we współczesnym świecie. Dużą rolę do spełnienia w Kościele przypisuje kardynał także seminariom duchownym, czemu dawał wyraz m.in. podczas spotkań z biskupami odbywanymi zarówno w siedzibie Kongregacji, jak i podczas swoich wizyt zagranicznych.

Niewątpliwie trwające blisko szesnaście lat kierowanie przez kard. Zenona Grocholewskiego Kongregacją Wychowania Katolickiego powala jednoznacznie przyjąć, iż jego wkład w dzieło edukacji katolickiej w świecie jest znaczący.

\section{Contribution of cardinal Zenon Grocholewski to international catholic educational efforts}

Born in 1939, cardinal Zenon Grocholweski, who worked in the Apostolic Signatura between 1972-1999, became the prefect for Catholic Education Congregation on 15 November 1999 and occupied this position for almost 16 years.

Having presented the biographical outline of Zenon Grocholewski, the author discusses the structure and competence of the mentioned Congregation and then presents the input of this cardinal-prefect in catholic education. Grocholewski's contribution into the development of three dimensions of the mentioned educational areas was presented according to the competencies of the Congregation dealing with the catholic education: seminaries (in 2013 they were assigned to the Congregation for the Clergy), catholic schools as well as catholic and church institutions of higher education. The author praises this contribution, underlining the engagement 
of the cardinal-prefect, who was concerned about the proper realization of the Congregation's tasks. His activity, both in Rome as well as during his foreign visits, should be held in high esteem.

SŁowA KLUCzowe: wychowanie katolickie, Kongregacja Wychowania Katolickiego, kard. Zenon Grocholewski

KEYwORDS: catholic education, Catholic Education Congregation, card. Zenon Grocholewski

Nota o Autorze:

Ks. PROF. ZW. DR HAB. WojCiech Góralski - pracownik naukowo-dydaktyczny na Wydziale Prawa Kanonicznego Uniwersytetu Kardynała Stefana Wyszyńskiego w Warszawie, kierownik Zakładu Kościelnego Prawa Rodzinnego, założyciel i redaktor naczelny rocznika, a następnie kwartalnika „Ius Matrimoniale”, wiceprzewodniczący Stowarzyszenia Kanonistów Polskich, konsultor Trybunału Roty Rzymskiej, członek Consociatio Internationalis Studio Iuris Canonici Promovendo, autor licznych prac z zakresu kanonicznego prawa małżeńskiego, historii prawa kanonicznego i prawa wyznaniowego. 